\title{
A COMPARISON OF THE TOXIC AND ALLERGIC REACTIONS OCCURRING WITH STREPTOMYCIN AND STREPTODUOCIN IN THE TREATMENT OF PULMONARY TUBERCULOSIS
}

\author{
F. Heyworth, M.B., Ch.B., and W. H. Helm, M.R.C.P. \\ Marsden Hospital, Burnley
}

\section{Introduction}

Riches $^{3,4}$ showed that the onset of transient reactions to streptomycin corresponds fairly closely to the peak blood levels.

The toxic effects of dihydrostreptomycin and streptomycin sulphate differ in some respects and it might be expected that by giving $0.5 \mathrm{~g}$. of both instead of $\mathrm{I} g$. of either of these preparations lower peak blood levels of each would be obtained, and a lower incidence of toxic and allergic effects might therefore be achieved.

The purpose of the present investigation is to compare the toxic and allergic reactions occurring during the use of this combination of drugs (streptoduocin) with those following the administration of $\mathbf{I}$. daily of streptomycin sulphate to a similar group of patients.

\section{Method}

The investigation took place during two consecutive years. All patients entering hospital during the first year were given streptomycin sulphate and those admitted to hospital during the second year were treated with streptoduocin. All patients who completed three months' treatment with either preparation, or in whom treatment had to be stopped because of a reaction, were included in the series.

Where necessary it was confirmed that streptomycin was the cause of the reaction rather than one of the other drugs (PAS or INAH) by stopping treatment, then re-starting it after resolution of the signs and symptoms.

\section{Results}

Table I.-Number of Toxic and Allergic Reactions OCCURRING WITH STREPTOMYCIN SULPHATE AND STREPTODUOCIN

\begin{tabular}{|c|c|c|}
\hline & $\begin{array}{l}\text { Strepto- } \\
\text { mycin } \\
\text { Sulphate }\end{array}$ & $\begin{array}{l}\text { Strepto- } \\
\text { duocin }\end{array}$ \\
\hline $\begin{array}{l}\text { Number of patients treated. } \\
\text { Number of patients having }\end{array}$ & 100 & \\
\hline $\begin{array}{l}\text { single reactions } \\
\text { Number of patients having }\end{array}$ & 22 & 40 \\
\hline double reactions . . . . & 球 & 8 \\
\hline $\begin{array}{l}\text { Number of patients having } \\
\text { triple reactions } \\
\text { Total number }\end{array}$ & 3 & $\mathbf{I}$ \\
\hline $\begin{array}{c}\text { Total number of patients } \\
\text { having reactions . } \\
\text { Total number of reactions } \ldots\end{array}$ & $\begin{array}{l}40 \\
61\end{array}$ & $\begin{array}{l}49 \\
59\end{array}$ \\
\hline
\end{tabular}

Table II.-Toxic and Allergic Reactions Occurring During Treatment with Streptomycin Sulphate AND STREPTODUOCIN

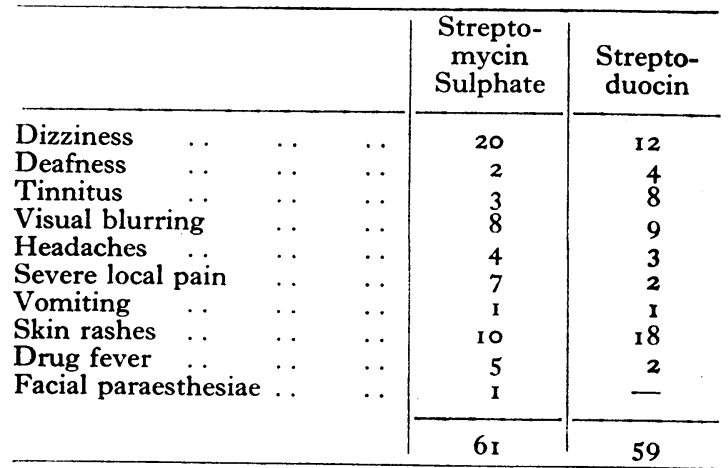

Further analysis of these reactions showed no definite advantage to either preparation in the total reactions occurring in female or male patients or in the individual age groups of either sex. 
TABLE 111.

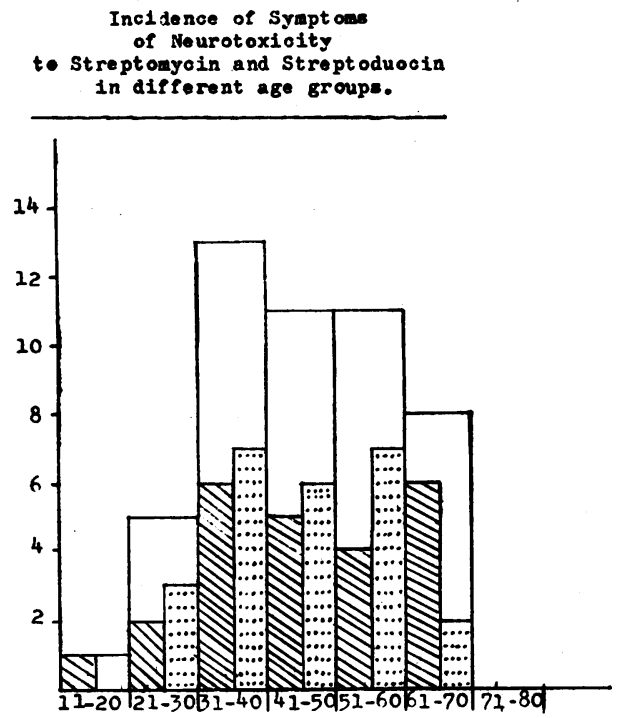

Streptoduocin

Strept omycin

Total
Table IV.-Neurotoxic Reactions Occurring in Patiknts Over 5o Yrars of Agr (53 Patiknts Trkated)

\begin{tabular}{|c|c|c|c|c|c|}
\hline & & & & $\begin{array}{c}\text { Strepto- } \\
\text { mycin }\end{array}$ & $\begin{array}{c}\text { Strepto- } \\
\text { duocin }\end{array}$ \\
\hline \multirow{4}{*}{$\begin{array}{l}\text { Deafness } \\
\text { Tinnitus } \\
\text { Dizziness }\end{array}$} & \multirow{4}{*}{$\begin{array}{l}\cdots \\
\cdots \\
\cdots\end{array}$} & \multirow{4}{*}{$\begin{array}{l}\cdots \\
\because \\
\therefore\end{array}$} & \multirow{4}{*}{$\begin{array}{l}\cdots \\
\cdots \\
\cdots\end{array}$} & I & 2 \\
\hline & & & & 2 & 2 \\
\hline & & & & 6 & 6 \\
\hline & & & & 9 & 10 \\
\hline
\end{tabular}

Thirty neurotoxic reactions occurred in 148 patients under the age of 50 , i.e. an incidence of roughly one reaction in five patients, whereas in the over $5^{\circ}$ age group 19 reactions occurred in 53 patients, an incidence of rather more than one reaction in every three patients treated.

There was no clear advantage to either preparation in the total incidence of neurotoxicity or in the over $5^{\circ}$ age group.

When the figures in Table $\mathrm{V}$ together with those resulting from a detailed 'breakdown' of the 'over six months group' are analysed by Students' t-test, the difference of their means is found to be highly significant statistically, the value of $t$ being over Io units with I 8 degrees of freedom.

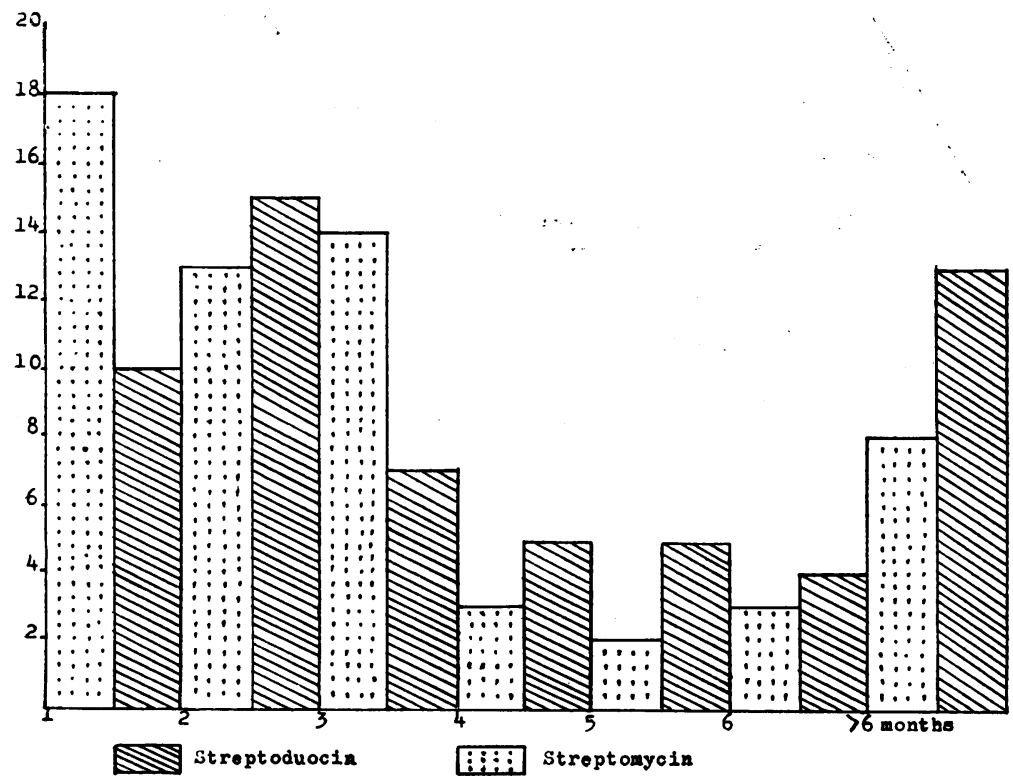


Table VI.-Number of Patien'ts Requiring Radical Change of Treatment Due to Reactions to StreptoMYCIN AND STREPTODUOCIN

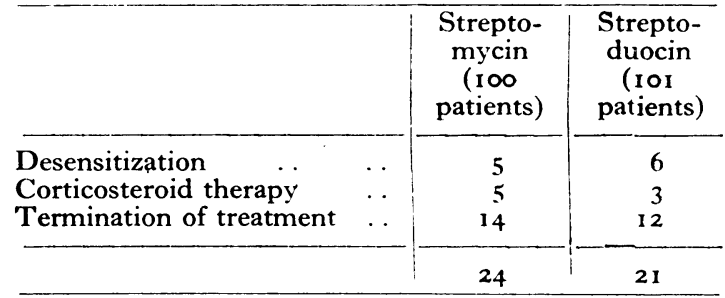

\section{Discussion}

Toxic and allergic reactions to streptomycin remain a considerable problem in the chemotherapy of pulmonary tuberculosis and, although many of the manifestations can be overcome at least temporarily by the use of antihistamines, corticosteroid drugs, or by desensitization, the symptoms may recur and cause further interruption of full treatment.

Ranger $^{2}$ emphasized the danger of eighth nerve neurotoxic effects with streptomycin and stressed the need for careful observation of patients under treatment. In spite of the fact that all our patients are questioned daily before the administration of streptomycin regarding the onset of tinnitus, deafness or dizziness, irreversible damage still occurs occasionally.

Lumsden and Powell ${ }^{1}$ compared the neurotoxic effects of streptomycin and streptoduocin in two groups of 20 patients. Vestibular disturbance occurred in 12 on streptomycin, and in five on streptoduocin, in whom symptoms were much less severe. Auditory loss did not occur on streptomycin, but three were slightly affected on the mixture. It was considered that streptomycin, I g. daily, was likely to cause disabling vestibular symptoms only in older patients, and for these the mixture was preferable.

Workers in other countries have published results both in favour of and against the routine use of streptoduocin, but the drug regimes have not been comparable to those generally accepted as essential in this country.

In the present series there was the expected preponderance of vestibular effects in the streptomycin group and of auditory effects in the strepto- duocin group, although surprisingly this was not found in the patients over 50 years of age. In the total incidence of eighth nerve toxic effects there was no definite advantage to either streptomycin preparation in the under 50 or over 50 age groups.

Our results as a whole show that a greater proportion of patients had reactions to streptoduocin than to streptomycin sulphate, but there were fewer multiple reactions. There was no clear advantage to either drug in any age group of either sex and a major change of treatment was required with almost equal frequency. The onset of reactions has, however, been on the average slightly later with streptoduocin (1 4.2 weeks) than with streptomycin (I I.8 weeks) and, therefore, longer periods of uninterrupted treatment have often been possible with the former. We have the impression that streptoduocin injections are usually less painful than streptomycin sulphate, and fewer of our patients complained of severe local pain with this preparation.

Although streptoduocin appears to have only slight advantages over streptomycin sulphate, we feel they are sufficient to encourage its use in patients whose hearing is normal. Routine audiometric studies during treatment would probably be of great value in demonstrating the earliest stages of loss of hearing when a change of regime might prevent permanent deafness.

\section{Summary}

Streptomycin sulphate was used for all inpatients for one year and streptoduocin for the next year. A comparison of the toxic and allergic effects was made. Although the advantages were slight, it was concluded that the streptoduocin was probably the drug of choice.

\section{Acknowledgments}

We wish to thank the nursing staff of the Marsden Hospital, Burnley, for their help in the investigation and Mrs. Withnell for the secretarial work.

\section{REFERENCES}

1. LUMSDEN, E. G. S., and POWELL, R. J. (1953), Tubercle, 34, 324 .

2. RANGER, D. (1959), Postgrad. med. F., 35, 344.

3. RICHES, H. R. C. (I954), Lancet, i, 540.

4. RICHES, H. R. C. (1954), Brit. F. Tuberc., 48, 298. 